\title{
Citizen Perceptions on Language and Dual Citizenship in the Democratic Republic of Congo: The Case of Goma City
}

\author{
Christian Koba Fazili1 ${ }^{*}$, Brigitte Muteba Byamungu ${ }^{2}$, Jacques Kyabula Katwe², \\ Déogratias Ilunga Yolola Talwa ${ }^{1,3}$
}

${ }^{1}$ Département des Langues et Affaires, Faculté des Lettres et Sciences Humaines, Université de Lubumbashi, Lubumbashi, République Démocratique du Congo

${ }^{2}$ Département des Sciences Politiques et Administratives, Faculté des Sciences Sociales, Université de Lubumbashi, Lubumbashi, République Démocratique du Congo

${ }^{3}$ Département de langues et civilisations françaises, Faculté des Lettres et Sciences Humaines, Université de Lubumbashi, Lubumbashi, République Démocratique du Congo

Email: *christiankoba@gmail.com

How to cite this paper: Fazili, C.K., Byamungu, B.M., Katwe, J.K. and Talwa, D.I.Y. (2021) Citizen Perceptions on Language and Dual Citizenship in the Democratic Republic of Congo: The Case of Goma City. Open Access Library Journal, 8: e6808.

https://doi.org/10.4236/oalib.1106808

Received: June 22, 2021

Accepted: August 9, 2021

Published: August 12, 2021

Copyright $\odot 2021$ by author(s) and Open Access Library Inc.

This work is licensed under the Creative Commons Attribution International License (CC BY 4.0).

http://creativecommons.org/licenses/by/4.0/

\begin{abstract}
The paper sought to explore the view of people in Goma city on the question of language and dual citizenship in the Democratic Republic of Congo (DRC). It also analyzed the constitutional provisions on citizenship. The liberal theory of citizenship by Micheal Lister was employed for studying on citizenship. The liberal theory of citizenship shares important aims and assumptions with radical citizenship approaches, which emphasizes democracy, voice and difference. This theory gives the importance of citizenship education and the multi-ethnicities engagement in the making and implementation of the Citizenship in the DRC. The study analyzed the law on citizenship and explored the view of people by observing them; the researcher used the questionnaire and the in-depth interviews with respondents in Goma city. A total of 102 participants participated in this study while the secondary data was sought from the constitution of the $24^{\text {th }}$ November 2004, accompanied by the organic law of the $18^{\text {th }}$ February 2006. The findings showed the facts people are founding holding dual citizenship while it prohibits in the DRC. Using documents and thematic analysis the study revealed that the government of DRC has to lift up the moratorium on citizenship debate at the National Assembly, allocate resources for the census to know who is and who is not Congolese and learn from others countries experiences on language and dual citizenship. The Congolese government must ensure the protection of applicants for citizenship and punish those who still hold dual citizenship. Finally, the government must bring the citizenship education in the everyday life of Congolese. It emerged
\end{abstract}


from the study that there is high corruption in government institutions, and the easy use and access of false document in Goma. The study recommended the government of the DRC to reevaluate the application of the law on citizenship and the roles of each government agency and institution in charge of the deliberating the citizenship issue. Finally, it recommended that the Government straighten the political relation with its all neighbor's countries.

\section{Subject Areas}

Sociology

\section{Keywords}

Citizenship, Language, Citizenship Law, Dual Citizenship, Identity's Conflict

\section{Introduction}

A state is deemed to exist at two definitive levels, that is: at the international level and at the national level. At the international level, a state is recognised as by its claim to sovereignty, political independence and status as being equal in status to other states in the international community [1]. From the national point of view, a state has to have a clearly bordered territory, with a population within it, that offers allegiance to the state and a well-organized political system that includes a government with authority over the entire population and territory [2]. Citizenship then comes into being where a state is able to fulfill its obligations to the citizens, often united by a common culture and language, who are willing and able to fulfill their obligations to the state [3]. As such, the issues of citizenship and language are intricately related to migration. In international law, migration is a function of citizenship; language as well, the duty to admit a person into the territory of a state is considered a right of citizenship [4].

According to article 13, paragraph 2, of the 1948 Universal Declaration of $\mathrm{Hu}$ man Right (UDHR), "Everyone has the right to leave any country, including his own, and to return to his country". Bound to national policies on immigration and integration, rules on citizenship essentially defined the boundaries between nationals and aliens. In order to define which foreigners or immigrants shall be permitted entry, each state must first decide how to define its own citizens or nationals (International Migration Policies, 1998).

Congolese citizenship is either by origin, or by individual acquisition. Any person belonging to an ethnic group of which the members and the territory are or were constituent to that which became the Congo (presently the Democratic Republic of the Congo) at independence on 31 June 1960, is of Congolese origin according to Article 4 (D-L n ${ }^{\circ} 197$ ) [5]. This paper will focus on citizenship by acquisition since it is one of the causes of conflict between the D.R.C. and its neighbours, Uganda, Rwanda and Burundi in the Great Lakes Region. Most of the people who acquire Congolese citizenship are from these neighbouring countries. 
According to the Congolese Official Bulletin of the I.E.C (1892, 326-328), Congolese citizenship is one and exclusive, meaning that it may not be held concurrently with any other [6].

Migrants from Rwanda have stayed in the DRC for a long time and, some have established themselves and acquired Congolese citizenship. As Congolese citizenship is exclusive, an applicant to it has to be prepared to renounce any other loyalties should they be granted citizenship. Some of the migrants have acquired citizenship using corrupt means because they do not want to go back to their countries fearing arrests or death.

Citizenship laws are especially important in Africa because of the large number of people who leave their countries of origin on the continent. Roughly one-third of the world's 15 million refugees are in Africa [7]. As a result, the question of who is and who is not a citizen of a particular country is tested daily. Furthermore, as a result of corruption in the department dealing with citizenship it is a real possibility that people who do not qualify for citizenship can end up in influential positions in a country over time after acquiring the status.

The issue of Congolese citizenship is one of many aspects that include the general population's ignorance of the law on one hand and non-compliance of the law on the other. It is a serious issue that needs to be viewed dispassionately in order to establish the link between the letter and the spirit of the law regarding citizenship. The insecurity resulting from granting citizenship status to foreigners without valid reasons needs attention.

\section{The Problem of Citizenship in the DRC}

The citizenship issue has been at the heart of many conflicts in post-colonial Africa, but political crises since independence in the DRC, show the same pattern: political leaders seek to buttress their support in one part of the country's population by excluding another from the right to belong to the country [7]. The failure or unwillingness by the state to carry out prescribed censuses and ignorance of the law are also a crucial problem in the D.R.C.

There has been an outcry from the members of the public that Congo is under siege with an influx of foreign nationals found holding Congolese citizenship and Congolese nationals holding foreigner citizenship in spite of the Constitution prohibiting this. The issue of dual citizenship in Congo appears to involve upper class individuals such as politicians and businessmen more than ordinary people. This problem is now being considered as one of the problems fuelling the unending identity conflict in Congo and the law needs to be reviewed or citizenship education implemented to respect the current law on citizenship.

\section{Why Write about Citizenship and Language}

The paper will first of all analyze the views of the Congolese in the city of Goma on the constitutional provisions on dual citizenship and the impact of foreign languages in the DRC. Secondly, the paper will show the perception of Congolese on 
their citizenship and their understanding of constitutional provisions. Finally, it will come up with suggestions for the review and better implementation of policies that protect the rights of Congolese citizenship.

\section{Area of Investigation}

Data for this paper were collected in the DRC, specifically in north Kivu, Goma town. There are nine countries bordering Congo, however, the paper would only be restricted to nationals from Rwanda, Burundi and Uganda as countries whose citizens acquire Congolese citizenship after escaping conflicts in their home countries. The research was focussed on the years between 1997 and 2013. Since 1997 was marked by the ascension to power of the AFDL under Laurent Desire Kabila with the support of the Great Lakes countries, since then the conflict increase in the eastern part of the DRC and the question of identity has become more pronounced in the country.

\section{Literature Review}

\section{The Liberal Theory and Human Needs Theory}

This paper was informed by the liberal theory of citizenship perceptions espoused by Micheal Lister. The liberal theory of citizenship emphasises that equality of rights, which each citizen holds, and how these rights enable the individual to pursue their aims and goals. Liberal theories of justice have given different answers to the question whether external closure can be justified. Jean-Claude, W. [8] distinguishes between admission to the territory and admission to membership and suggests that territorial borders must remain at least potentially closed in order to keep the boundaries of membership open for newcomers. Another author Carens [9] argues against this view that from a perspective of global justice closed borders for immigration turn liberal citizenship into the equivalent of a feudal privilege.

The liberal citizenship theory sees language, communication and speech as having the central role of the interactive process through which it understands the world and itself. The liberal citizenship theory was used to examine the perceptions of Congolese on dual citizenship in DRC. There is a deepening of the concept, because citizenship no longer exclusively relates to the political level, but also extends to the social and the cultural levels and even to the interpersonal level. The broadening and especially the deepening of the concept means that citizenship increasingly relates to a person's identity.

The human need theory espoused Maslow and Burton [10] complement the liberal theory of citizenship as it states that humans need a number of essentials to survive. These essentials go beyond just food, water, and shelter. They also include both physical and non-physical elements needed for human growth and development, as well as all those things humans are innately driven to attain [11]. For Maslow and Burton, needs are hierarchical in nature. That is, each need has a specific ranking. Maslow's needs pyramid starts with the basic items of food, 
water, and shelter (Figure 1). Furthermore, they contend needs do not have a hierarchical order. Rather, needs are sought simultaneously in an intense and relentless manner.

The human needs theory argues that one of the primary causes of protracted or intractable conflict is people's unyielding drive to meet their unmet needs on the individual, group, and societal level [10]. For example, the identity conflict in North and South Kivu involves the unmet needs of identity and security. Countless Congolese who acquired citizenship feel that their legitimate identity is being denied them. Numerous Congolese feel they have no security at an individual level due to persistent talk questioning their citizenship status on the basis that they are not originally from the DRC.

Congolese by acquisition need to be accepted by others and to have strong personal ties with one's family, friends, and identity groups. They also need to be recognized by others as strong, competent, and capable. The human need also includes the need to know that one has some effect on her/his environment Burton. The need to reach one's potential in all areas of life. The need goes beyond a psychological "sense of self." Burton [10] and other human needs theorists define identity as a sense of self in relation to the outside world. Identity becomes a problem when one's identity is not recognized as legitimate, or when it is considered inferior or is threatened by others with different identities. It brings in the aspect of the distributive justice which is the need for the fair allocation of resources among all members of a community and the participation which is the need to be able to actively partake in and influence civil society.

\section{Methodology}

\subsection{Cases Study Approach}

The case study method was used in this paper to evaluate the challenges that affect the perceptions of Congolese and the constitutional provision on citizenship and language in the DRC. The study focused on the perception of citizens on the question of dual citizenship and also of language in the DRC the case of Goma

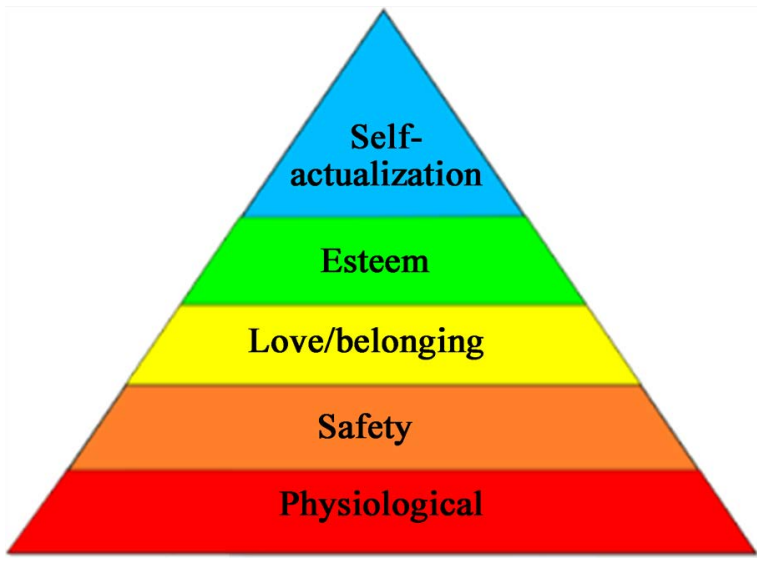

Figure 1. Maslow's needs pyramid. 
City. The researchers used documentary sources, observation, interviews and questionnaires to collect data using mixed methods. Yin [12] defines a case study as, "an empirical inquiry that investigates a contemporary phenomenon in depth and within real context, especially when the boundary between the phenomenon and the context are not clearly evident.

The researcher used a case study approach to bring an in-depth study on the perception of Congolese in Goma City on the constitutional provision of dual citizenship. This was likely to give valid and reliable results, since it was the same reality in the three provinces in the eastern part of Congo. mixed methods research was used to gain insight into the opinion of the people, who are considered themselves as original Congolese (majorities) and see others as non-Congolese because they are minorities.

The case study approach, using descriptive survey, was the most appropriate since it could use a sample. The problem of identity remains the same in all provinces bordering the nine countries surrounding the DRC. Another advantage was that, the case study made it possible to use research instruments such as, questionnaires, interviews and observation. This triangulation was important in a study such as this, although the interview and observation were greatly used in this study.

\subsection{Population}

The target population is the population of individuals which a research is interested in describing and making statistical inferences for the study. Goma city has around 501306 residents according to the 2010 census (Bureau d Etuded Amenagement et Urbanisme, 2011). This study purposively sampled 120 leaders of various institutions ranging from political, civic to social ones. In the case of Goma city, the sample was all well informed on the question of citizenship and this represents $55 \%$ of the population and is considered to be representative of the population and inform on the issue of citizenship in the DRC.

Through participant observation, the researchers observed how people in the city of Goma related to each other in social spaces such as churches, work or in recreation. The groups observed were made up of Congolese by origins, Congolese by naturalisation, refugees and Banyarwanda. The purpose was to establish how the majority claims to be Congolese and segregate minorities, how they reacted to and perceive each other, the researcher observed also all movement of people at the border when they are getting in and out of the country, all of these the researcher observed whilst interviewing people on the question of identity and gathered some information on citizenship in the DRC.

\subsection{Data Analysis}

The researchers cleaned and coded data before entering the data into the SPSS Software for analysis and the descriptive results of the case study were displayed in tabular and graphical. The in-depth interviews with all the leader members of 
each category and the observation made during the research thematic analysis was used and the results similarly compared to the liberal citizenship theory discussed in above as well as the research questions and objectives basing on impacts of the constitutional provision on dual citizenship in the DRC.

\section{Results}

One hundred and twenty (120) questionnaires were distributed and hundred and two (102) were returned. The hundred and two (102) questionnaires returned from the participants showed an eighty-five (85\%) response rate and it was considered as excellent response rate. Best and Khan considered a response rate of 50\% as adequate, and one of $85 \%$ response rate is considered as excellent [13].

As indicated in Table 1, the gender of the respondents signifies that out of the 102 questionnaires returned, 60 (58.8\%) of the participants who were involved are male and $42(41.1 \%)$ are female who gave their view on citizenship issue in the DRC. The researcher distributed 60 questionnaires to men and 60 to women for gender parity. The study indicates that male participated more compared to female on this citizenship issue. In this way, the result reflects an almost equitable distribution of respondents by gender giving balance.

The age group of the respondents signifies that out of the 102 respondents, 23 respondents were more than 50 years both 13 males and 10 females. The greatest number of respondents were between the ages of 30 - 39 years which constituted 31 respondents, 20 males and 11 females. The age group of $20-29$ years had 28 which were mainly made by 20 male Goma's youth leaders and only 8 females, while the age group of $40-49$ years constituted 20 respondents and 7 males and 13 Female.

The fact that the 30 - 39-year-old range proved to be the most numerous to return fully completed questionnaires may be explained by the fact that citizens from this range were born around the time when the conflict raised in neighbouring countries and they experienced the migration in and out of the country. Critically, this is the age range when people are seeking stability through family, career and belonging to a social order and if the Congolese state does not provide it to them or restricts their access they may end up looking for other ways.

Table 1. Désagrégation of respondents and response rate.

\begin{tabular}{cccc}
\hline Class of respondents & Data collection methods & Respondents & Response \% \\
\hline $\begin{array}{c}\text { Lawyers and Political parties' } \\
\text { members }\end{array}$ & Questionnaire Interviews & 37 & 92.5 \\
$\begin{array}{c}\text { University's members } \\
\text { Electoral commission, census } \\
\text { servants and Immigration servants }\end{array}$ & Questionnaire Interviews & 29 & 72.5 \\
Goma's youth leaders & Questionnaire Interviews & 20 & 80 \\
Total & & 102 & $\mathbf{1 0 0}$ \\
\hline
\end{tabular}




\subsection{Census Considerations}

Table 2 shows that most of people of the group age 20 - 29 and 30 - 39 from the findings were 20 males and 19 females in these age group and who received at least twice the electoral card, this obvious from the 2006 electoral enrolment and the one held in 2011. The findings reveal that the numbers of people in the DRC are always referring to the 2006 and 2011 registration. The researchers noticed that the process of acquiring this card in the DRC remains very weak. As an illustration, the simple fact that someone can be in Congo during the registration period can make him/her obtains the electoral card.

On the one hand, all non-Congolese who are Bantu and who can speak a language or dialect from the DRC can get this card easily. Additionally, corrupt practices at the government department responsible also facilitate the fraudulent acquisition of Congolese citizenship. On the other hand, a Congolese who have acquired another citizenship can come back to the DRC and get it without any process ensuring that the foreign citizenship is cancelled according to the law.

Although, the electoral card in the DRC remains the only official identity card, this means any foreigner who secures it, automatically becomes Congolese without asking for the Congolese citizenship, and Congolese who had another identity, in both cases they have dual citizenship because holding dual nationality. Beside the electoral card, the driving license can be also used as an identity card, another and better one the passport is also used as the identity card.

In the age group 40 - 49 most people from the findings received it at least twice. The last census in the DRC dates from 1985 and people in this age group where still minors. In the 2005 referendum the country adopted the five years' term for elections. After each five years the country will organize the registration of the population to vote for their leaders. The researcher's analysis showed that, the lack of objective data per electoral district concerning the number of inhabitants, their ages, their sex, was in the previous elections (2006 and 2011) the most important cause of disputes over the question of citizenship in the DRC and today the disputes of the results between candidates for the different elections.

Other Congolese in the group age 20 - 29 obtain the electoral card more than once in the same period. This affects the statistics of the enrolment. The last age group more than 50 years, 23 respondents 13 male and 10 females, most of people

Table 2. Numbers of censeur.

\begin{tabular}{cccccccc}
\hline & & \multicolumn{5}{c}{ Number identity card } & \multirow{2}{*}{ Total } \\
\cline { 3 - 6 } & & less than once & once & twice & three times or more & \\
\hline Groupag & $20-29$ years & 3 & 11 & 12 & 2 & 28 \\
& $30-39$ years & 7 & 6 & 12 & 6 & 31 \\
$40-49$ years & 1 & 5 & 8 & 5 & 19 \\
more than 50 & 1 & 5 & 11 & 7 & 24 \\
Total & 12 & 27 & 43 & 20 & 102 \\
\hline
\end{tabular}


received at least twice the electoral card. This shows that in the DRC, there was no citizenship education and still females were excluded in the politics, and had lower education than men. From the findings the pattern showed that in the DRC there is no periodic census and lack of an institution in charge of identification. Respondents argued that the weakness of the institutions allow people to hold dual citizenship while the constitution prohibits it.

\subsection{The Impact of the Constitutional Provision on Dual Citizenship}

Article 10 of the Constitution of the DRC as revised to date proclaims: "Congolese nationality is one and exclusive. It may not be held concurrently with any other one". One of the most important aspects of the Congolese citizenship law is the exclusivity of Congolese nationality. However, in spite of this people do hold dual citizenship as the study found. It seems to be a problem of essentials human needs which are unmet by the people as a result of inability to provide. This pushes Congolese of origin to look for security on one side and the other side people foreigners are taking advantage to this situation to have citizenship and enjoy the right of being Congolese.

Indeed, since the DRC secured independence, the question of nationality has become acute, as it is true that the foreign populations who immigrated to the Belgian Congo during colonization were still not regarded by indigenous peoples as national populations. To resolve this question in 2004 the Delegates to the Inter-Congolese Dialogue had decided to put an end to the social divide resulting from quarrels over the issue of nationality of origin, in order to restore social peace between all layers of the population.

This research study interviews held on the $5^{\text {th }}$ February 2017 with universities members and political parties' leaders. The respondents said that the constitution is clear on the citizenship issue and the conditions to acquire it are well defined in the citizenship law of the DRC. It is sad to notice that on the field the law is not respected. From the respondents a huge number of Congolese have dual citizenship while it is prohibited in the citizenship law of the DRC.

The researchers argued, from the findings, that some Congolese of origin in power, business, politicians and some foreigners who have become Congolese by acquisition seek to manipulate the law on citizenship in the Congo for their private and personal purposes. Also, for them to have an easy access and oversee the internal and external business, to have a refuge in case of political exile, easy access to mining in North Kivu. This is the major point of citizenship conflict which shaped the view of people in Goma.

Respondents continued to perceive those Congolese as foreigners. From these views, there is a need to amend the law on citizenship; the legislature must pass a new law that will be equal and applicable to all Congolese. Legislators must democratize citizenship to give equal chances to all citizens in the DRC which can be internally inclusive but externally exclusive and bounded; all citizens can have an equal voice and right. It can be accepted that Congolese of origin and fo- 
reigners who have acquired Congolese citizenship may have a second citizenship with some restrictions; if it externally inclusive, then they will no longer be able to accede to high functions of the state.

\subsection{The Law Is Not Well Defined and Is Subject to Confusion}

The Organic Law of the $18^{\text {th }}$ February 2006 is a document that was viewed with a lot of interesting notions, it was discovered that there was a comprehensive interpretation of the citizenship law by personnel working in government, immigration, political parties and including civil society organizations. Indeed, there is a shift between politics, the morals and the law; all evolution is commanded by the political forces. René Cassin says that the equal right of all citizens to participate in the political and social life of a country or to accede by the merit in political functions, equality of the country or of merit in political functions, maintains a regime of freedom, reciprocally equality does not exist where freedom is unknown [14].

Willame [15], in his book Banyarwanda and he Banyamulenge and Brice (1981) in Ethnic Conflict in North Kivu say that in the 1981 years a group called Rwandan People in Zaire sent a letter to the Secretary-General of the United Nations (U.N.) requesting authorization to establish a separate and independent State in North Kivu. They hoped that the UN and the Organization of African Union (OAU) would recognize their claim to self-determination. However, the minority of respondents interviewed proved to be ignorant of the Organic Law, but informed the researchers that, in July 1991, the Banyamulenge intellectuals' claim to the national sovereign conference seeking a legal framework for the protection of the rights of ethnic minorities. Respondents acknowledged that in practice, when tents to seek outside the mechanisms established by the State, the means of hastening the concretization of the equality of citizens, there is a resistance constituted by the imperatives of national unity.

One of the respondents stated that to understand the political and legal situation of individuals in the colonial state before independence in the Congo, it is necessary to know that there existed a Congolese nationality, a proper quality attributed to the colonized, but that in practice, the colonial's rulers had laid down his legislation both to increase the number of his subjects and to assimilate those of the other powers in Africa (university student, Interview 2, 05 January 2017).

\subsection{The Challenges of Citizenship Law in the DRC in Terms of Importance}

From the questionnaire response and the interviews with respondents the researchers came up with four challenges of the citizenship law in the DRC which can be only solved if the human need is provided by the government of the DRC to citizens. The citizens need freedom, liberty of expression, belongingness and love to the country, but these are still challenge by: 
7.4.1. The Lack of Census of the Population (Almost Nonexistent) and Lack of the Numeric Data

Absence of regular census in the country. It will help to know Congolese of origin, acquisition (naturalization, option, adoption and marriage).

\subsubsection{Ignorance of the Law}

Lack of the citizenship education in everyday life of Congolese and the constitution is problematic. Lack of information of acquiring Congolese citizenship and people prefer to use both their origin and the new one which creates confusion.

\subsubsection{Lack of Reliable Information on the Criteria of Procurement Congolese Nationality}

The study found widespread confusion regarding which ministry is responsible for citizenship matters. The confusion revolved around the ministries of justice, interior and foreigner's affairs or the National Assembly. The centralization of the process in the capital city was also revealed to be a challenge. Findings from this research found that the use of false documents by foreigners contribute to the failure of the process and bring the problem of people holding dual citizenship.

\subsubsection{Precariousness in the Services in Issuance Birth Certificate and Permits}

Failure to give the right documents on time and weak processes in the procurement of these papers. Ineffective governmental controls on the question of citizenship. This is due to Social injustice. Tribalism, conflicts, violence and war in Goma city, exaggerated corruption of political authorities.

Other causes obtained from primary data are shown in tables below:

\subsection{Corruption in Government Entities}

It emerged that 37 (36.3\%) strongly agree that the DGM and the CENI are more corrupted, 41 respondents (40.2\%) agree and this is the highest rate of respondents, this shows the weakness of the institutions, foreigners can have the citizenship in the DRC easily using corruption, and this result in foreigners obtaining electoral and the identity card to vote for some leaders in power during elections.

The Congolese government must punish all those who are corrupt both officials and those seeking services. It was established during the research that lack of appreciation and understanding of the article 10 of the Constitution was part of the root causes for corrupt behavior and lack of adherence to the legal provisions provided in the Organic Law of 2006.

\subsection{Implication of the Organic Law in the DRC}

The Impact of the Constitutional Provision on Dual Citizenship

Although the Organic Law on Citizenship says the Congolese citizenship is one and exclusive, the reality on the ground remains different. The first cause can be 
the absence of an exhaustive census of the tribes on the Congolese borders at the date of their definitive location and also the inaccuracies that still exist, all penetrations are permitted in Goma. This means that the Congolese law has chosen a problematic criterion, because it has a somewhat vague character. Because people are always in movement and foreigners use that opportunity to claim the citizenship. The difficulty lies in the reference to the tribe and the level of individuals that the law wants to identify.

The second cause is also the tribal criterion and it implies that tribes settled in the Congo after 1885, and that their members cannot claim Congolese citizenship, or that persons belonging to none of the tribes existing in that country, are installed there after this date, that is to say after the conquest by the Europeans.

In a direct way: the natural increase of populations, mass migration (organized and unorganized, but in all cases imposed on local populations), the arrival of new land actors who appropriated not only the former colonial plantations but also part of the land cultivated by the peasants. The evolutions of the neighbouring country by spontaneous the influxes of the Hutu and Tutsi refugees, migrants in Goma city is also at the root of conflict over citizenship. The same forced reception was finally imposed by the central government of Kinshasa and by the international community.

This brings two impacts of structural characteristics: the weakness of the formal institutions of the State and the importance of the clientelist relations within this same state. It is in this context that the dispute over the "question of dual citizenship" of the Rwandan, Burundian and Ugandan populations who have arrived at different times in the Congo has gradually been expressed in an increasingly conflicting and inextricable way, also some Congolese from origin who have acquired citizenship from others country.

\subsection{Assessment of the Enjoyment of the Right to Congolese Citizenship}

Effective Tools of Assessments are Available to Evaluate Performance of the Congolese Citizenship

The data revealed that 8 respondents (7.8\%) strongly agree, 10 respondents $9.8 \%$ agree, 34 respondents (33.3\%) are neutral, 21 respondents (20.6\%) disagree and 29 respondents $(28.4 \%)$ strongly disagree that the effectives tools of assessments are available to measure performance of the Congolese citizenship as a whole in the sense that who is really Congolese of origin and those who have acquired the citizenship, are they enjoying the all right as the one of origin.

These findings show that there are no effective tools of assessment for measuring performance as a whole available in the DRC. 51 respondents (49\%) disagree, that why amongst the strategies it suggests to allocate more money to the citizenship issue by the government for census and citizenship education. To allow those who have acquired the citizenship to fully enjoy the right as Congolese, if they renounce completely to their first citizenship. 


\subsection{Consultation of Leaders in the Decision Making on Citizenship}

Political Leaders, Lawyers and Youth Leaders of Goma are Associated to the Decision Making of the Issue on Citizenship

Findings from the field (Table 3 ) indicate that only $7.8 \%$ of respondents strongly agree and $11.8 \%$ agree that political leaders, lawyers and Goma's youth leaders are associated to the decision making concerning the issue on citizenship whereas $28.4 \%$ strongly disagree and $19.6 \%$ disagree. $32.4 \%$ is neutral about this. These findings show that there is no consultation of political leaders, lawyers and Goma's youth leader regarding the citizenship issue in the DRC.

\subsection{The Strategies in Place to Resolve the Issue of Dual Citizenship in the DRC}

This research comes up with six strategies that the government through its legislature can adopt to resolve the citizenship issue in the DRC.

\subsubsection{To Lift up the Moratorium Question on Citizenship at the National Assembly}

The parliament must address the root causes of the problem due to land and ethnicity conflict and discuss it seriously. The facts are there people are holding dual citizenship in Goma city.

\subsubsection{To Allocate Resources for the Census}

The irregularity and rarity of census contributes to the confusion and conflict. The government must find ways to allocate money for a regular census in the all country. Also, the government must decentralize the decision making on the process of acquiring citizenship in the DRC. The lawyers, political leaders, youth and the community must be informed to avoid a bad perception of others citizens.

\subsubsection{Learn from Experiences of Other Countries}

The Congolese government must look at other countries' experiences on dual citizenship issue in Africa like Ghana, South Africa, Rwanda, and Nigeria and see how it works in their country and try to integrate it in the DRC to resolve the land problem and the ethnic conflict which took place since the Berlin conference in Africa.

Table 3. Valid data.

\begin{tabular}{cccccc}
\hline & & Frequency & Percent & Valid Percent & Cumulative Percent \\
\hline \multirow{2}{*}{ strongly agree } & 8 & 7.8 & 7.8 & 7.8 \\
agree & 12 & 11.8 & 11.8 & 19.6 \\
Valid & neutral & 33 & 32.4 & 32.4 & 52.0 \\
& disagree & 20 & 19.6 & 19.6 & 71.6 \\
& strongly disagree & 29 & 28.4 & 28.4 & 100.0 \\
& Total & 102 & 100.0 & 100.0 & \\
\hline
\end{tabular}




\subsubsection{Checks and Balances on Government Ministries}

The checks and balances of the authority amongst the ministries and services in charge of birth, residence, and student permit in the DRC and the process of citizenship. The procedure must be clear from the demand to the option of all permits in the DRC. The Congolese government must put in place a structure to control if the applicant has renounced totally to his/her citizenship of origin to enjoy completely the Congolese citizenship.

\subsubsection{Protection of Applicants for Citizenship}

The protection of the applicant during the process of is application and after getting the citizenship by acquisition in Goma town particularly and in the all country in general. There is need to define the structure which can work for every applicant and have to comply with the law, regulation and acquisition mode of the Congolese citizenship.

\subsubsection{Citizenship Education}

The government needs to introduce and maintain a programme on citizenship education from primary school to university within the broader framework of civic education. This can be supplemented by the production of mass media output on the same themes. This would address the problem of general ignorance on the laws governing citizenship noted in respondents.

\section{Summary}

This paper presented, analyzed and discussed funds. Data was presented and analyzed under the following themes: internal and external challenges faced by the Constitution of the DRC on it Article 10, the citizenship law, the causes of the identified challenges, the strategies in place to resolve the question on conflict identity in the DRC and the question of citizenship issue. In analyzing the data, the researcher discovered the possible strategies that can be employed by the Congolese government thus satisfying the objectives of this study.

\section{Author Contribution}

All of the authors of this article made significant contributions to the design, implementation and/or analysis and interpretation of the data, article development, and review criticism of its intellectual content.

\section{Contributors}

Study design: Christian KOBA Fazili, Brigitte MUTEBA Byamungu, Jacques KYABULA Katwe;

Data collection: Christian KOBA Fazili, Brigitte MUTEBA Byamungu;

Data analysis: Christian KOBA Fazili, Jacques KYABULA Katwe, Brigitte MUTEBA Byamungu, Déogratias ILUNGA YOLOLA.

\section{Drafting of the Manuscript}

All authors. 


\section{Conflicts of Interest}

The authors declare no conflicts of interest.

\section{References}

[1] Young, C. (2007) Nation, Ethnicity, and Citizenship: Dilemmas of Democracy and Civil Order in Africa. In: Nugent, P., Hammett, D. and Dorman, S., Eds., Making Nations, Creating Strangers: States and Citizenship in Africa, Brill Academic Publishers, Leiden, 241-264. https://doi.org/10.1163/ej.9789004157903.i-280.83

[2] Ndegwa, S.N. (1997) Citizenship and Ethnicity: An Examination of Two Transition Movements in Kenyan Politics. American Political Sciences Review, 91, 599-616. https://doi.org/10.2307/2952077

[3] Manby, B. (2010) Citizenship Law in Africa A Comparative Study. African Minds, Cape Town.

[4] Plender, J. (1988) Foreign and Native on the English Stage, 1588-1611 Social Subjectivity. Palgrave Macmillan, London.

[5] Assemblée Nationale de la République Démocratique du Congo (2005) The Democratic Republic of Congo: Constitution 2005, Kinshasa, annal parlementaire de la première législature. Loi No. 1972-002 du 5 janvier 1972 relative à la nationalité zaïroise; Loi No. 1981-002 du 29 juin 1981 relative à la nationalité zaïroise; Loi No. 04-024 du 12 novembre 2004 relative à la nationalité congolaise.

[6] Assemblée Nationale de la République Démocratique du Congo (2005) The Democratic Republic of Congo: Constitution 2005, Kinshasa, annal parlementaire de la première législature.

[7] Manby, B. (2009) Struggles for Citizenship in Africa. Zed Books, London. https://doi.org/10.5040/9781350222830

[8] Jean-Claude, W. (1998) Kivu: La poudrière. In: GRIP, Kabila prend le pouvoir, GRIP, édition complexe, Bruxelles, p. 43.

[9] Carens, J.H. (1987) Aliens and Citizens: The Case for Open Borders. The Review of Politics, 49, 251-273, 23 p. https://doi.org/10.1017/S0034670500033817

[10] Burton, J. (1997) Violence Explained: The Sources of Conflict, Violence and Crime and Their Provention. Manchester University Press, Manchester

[11] Sizwebanzi Mngomezulu, M. (2015) Citizenship in the colonial Africa (An overview of British and French Repertoires.

[12] Yin, R.K. (2009) Case Study Research: Design and Methods. 4th Edition, SAGE Publications Inc.

[13] Khan, S. and Best, L.Y. (2001) The Value of the Aggregate Data Approach in MetaAnalysis with Time-to-Event Outcomes. Journal of the Royal Statistical Society: Series $A$ (Statistics in Society), 164, 357-370. https://doi.org/10.1111/1467-985X.00207

[14] Pichon, M. (2007) René Cassin, la Passion for France and Human Rights: The Life of a French Israelite. Archives Juives, 40, 100-109. https://doi.org/10.3917/aj.402.0100

[15] Russett, B.M. (1965) Trends in World Politics. Macmillan, Co., New York. 